\title{
Bali Bananas (Musa spp. L.) Genetic Relationship Based on Internal Transcribed Spacer 2 (ITS-2)
}

\author{
Fenny Martha Dwivany ${ }^{1,2,5 *}$, Muhammad Rifki Ramadhan ${ }^{1}$, Carolin Lim ${ }^{1}$, Agus \\ Sutanto $^{3}$, Husna Nugrahapraja ${ }^{1,2}$, Ketut Wikantika ${ }^{2,4,5}$, Sigit Nur Pratama ${ }^{1}$, Karlia \\ Meitha $^{1,2}$ and Aksarani Sa Pratiwi ${ }^{1,2}$ \\ ${ }^{1}$ School of Life Sciences and Technology, Institut Teknologi Bandung, Jl. Ganesa 10, Bandung 40132, \\ West Java, Indonesia \\ ${ }^{2}$ Bali International Research Center for Banana, Gedung Widyasaba lt. 3 Sayap Selatan Kampus UNUD \\ Bukit Jimbaran Kuta Selatan Badung, Bali, Indonesia \\ ${ }^{3}$ Indonesian Tropical Fruit Research Institute, Jl. Raya Solok Aripan Km. 8 PO Box. 5 Solok 27301, \\ West Sumatara, Indonesia \\ ${ }^{4}$ Faculty of Earth Sciences and Technology, Institut Teknologi Bandung, Jl. Ganesa 10, Bandung 40132, \\ West Java, Indonesia \\ ${ }^{5}$ Center of Remote Sensing, Institut Teknologi Bandung, Jl. Ganesa 10, Bandung 40132, West Java, \\ Indonesia
}

\begin{abstract}
Banana is one of the most essential commodities in Bali island. It is not only for nutrition sources but also for cultural and religious aspects. However, Bali banana genetic diversity has not been explored; therefore, in this study, we focused on its genetic relationship using a molecular approach.

ARTICLE INFO

Article history:

Received: 22 July 2020

Accepted: 21 September 2020

Published: 27 November 2020

DOI: https://doi.org/10.47836/pjtas.43.4.12

E-mail addresses:

fenny@sith.itb.ac.id (Fenny Martha Dwivany)

rifki1896@gmail.com (Muhammad Rifki Ramadhan)

carolinlia12@gmail.com (Carolin Lim)

bagusutanto.03@gmail.com (Agus Sutanto)

husna.np@gmail.com (Husna Nugrahapraja)

wikantika.ketut@gmail.com (Ketut Wikantika)

sigitnurpratamashift@gmail.com (Sigit Nur Pratama)

karliameitha@gmail.com (Karlia Meitha)

pratiwiaksarani@gmail.com (Aksarani Sa Pratiwi)

*Corresponding author

This research aimed to determine the genetic relationship of Bali banana cultivars using the internal transcribed spacer 2 (ITS-2) region as a molecular marker. A total of 39 banana samples (Musa spp. L.) were collected from Bali island. The ITS-2 DNA regions were then amplified and sequenced from both ends. ITS-2 sequences were predicted using the ITS2 Database (http://its2.bioapps.biozentrum. uni-wuerzburg.de/). The multiple sequences alignment was performed using ClustalX for nucleotide-based tree and LocARNA to
\end{abstract}


provide the secondary structure information. Phylogenetic trees were constructed using neighbor-joining (Kimura-2-parameter model, 1,000 bootstrap). The result showed that two clades were formed, one clade was abundant in A genome (AA and AAA), and the other rich in the $\mathrm{B}$ genome $(\mathrm{BB}$ and ABB). This result suggested that cultivars that had similar genomic compositions tended to be grouped within the same clade and separated with different genomic compositions. This study gives perspectives that ITS-2 sequences in bananas are quite similar and differ much compared to other families. Secondary structure has been described to provide more robust resolving power in phylogenetic analysis.

Keywords: Genetic diversity, ITS-2, phylogenetic tree, secondary structure

\section{INTRODUCTION}

Banana is one of the most important crops, with 100 million metric tons being produced annually in 130 tropical and subtropical countries (Pillay \& Tenkouano, 2011). It was reported that bananas were initially derived from naturally crossing of bananas in Papua New Guinea and Eastern Indonesia, then differentiated and spread to Southeast Asia and finally throughout the world (Nelson et al., 2006). In Indonesia, banana is a valuable commodity with the highest biodiversity throughout the country (Hapsari et al., 2017). Particularly on the island of Bali, in which most of its inhabitants are Hindus, bananas have pivotal roles in the procession aspects of the customs, culture, and religious ceremonies. Not only in quantity, but the diversity of bananas is also crucial for the people of Bali, especially for custom processions and offerings (Rai et al., 2018).

DNA barcoding is a method used in species identification using standard areas of DNA in an organism. This method uses short molecular markers in organism DNA and is considered promising to identify species of an organism and determine their relationship with one another. The molecular markers used should be variable enough and enable closest species identification but need to be conservative to simplify PCR amplification and alignment of sequences among distant species. One type of molecular marker used universally is the internal transcribed spacer (ITS) (Zhang et al., 2015).

Most of the banana accessions are polyploid (diploid or triploid) and believed that various cultivars originated from intra- and inter-specific hybridizations between wild bananas of Musa acuminata (A genome) and Musa balbisiana (B genome) (De Langhe et al., 2009). To date, the immense diversity of banana cultivars on the island of Bali has not been fully explored, especially in the aspect of genetics and molecular biology. To the best of our knowledge, there are some molecular studies on banana in Indonesia (Hapsari et al., 2018; Meitha et al., 2020). However, there was no report on banana molecular relationships in Bali. As one of the most popular markers in phylogenetics, ITS-2 sequences are considered accurate owing to their conserved nucleotides. As a means of 
identification by using the DNA barcoding method, ITS-2 can supplement the use of morphological characteristics analysis (Guzow-Krzemińska \& Wȩgrzyn, 2000).

ITS is a region located between the ribosomal rDNA locus. This region is often used by researchers to determine biodiversity and molecular relationship, especially in plants. The molecular marker of the ITS region is chosen because it has several advantages. The ITS area is relatively short (at around $200 \mathrm{bp}$ ) and has a high-copy-number in the genome, making it easier to be isolated, amplified, and analyzed (Poczai \& Hyvönen, 2010). ITS2 region, the primary source of variations in the ITS sequence, is shorter and easier to be sequenced. Besides, the ITS-2 region exhibits significant sequence variability at the species level or lower (Yao et al., 2010). Therefore, the ITS- 2 region has been considered as an excellent phylogenetic marker and a promising standard region for barcode DNA (Zhang et al., 2015). The purpose of this research is to determine the genetic variability of banana cultivars in Bali Island using the ITS-2 region as a molecular marker.

\section{METHODS}

\section{Tissue Collection and Preservation}

We collected thirty-nine cultivars of bananas from nine regencies in Bali, as presented in Table 1 and Figure 1 was visualized according to area coordinates, as shown in Table 2. Cultivars were sampled one replicate by cutting approximately $10 \mathrm{~cm}$ of the cigar leaves with a sterile blade and stored in a $50 \mathrm{~mL}$ conical tube filled with 2 $\mathrm{g}$ silica gel $\left(\mathrm{SiO}_{2}\right)$ to reduce the humidity. Once arrived in Bandung, liquid nitrogen was used to preserve the cigar leaves and leaves were stored in $-80^{\circ} \mathrm{C}$ before used.

Table 1

Banana cultivars collected from Bali island

\begin{tabular}{llllll}
\hline No. & Cultivar & Locality & No. & Cultivar & Locality \\
\hline 1. & Kayu & Gianyar & 11. & Sobo & Klungkung \\
2. & Sabe Macan & Klungkung & 12. & Buah & Karangasem \\
3. & Mas Bali & Gianyar & 13. & Ketip Kerta & Gianyar \\
4. & Sangket & Klungkung & 14. & Poh & Gianyar \\
5. & Keladi & Klungkung & 15. & Bali & Gianyar \\
6. & Tulang & Gianyar & 16. & Lumut & Gianyar \\
7. & Kepok & Klungkung & 17. & Ambon & Gianyar \\
& Tanjung & & & Kuning & \\
8. & Rojo Molo & Klungkung & 18. & Mas Marlin & Gianyar \\
10. & Tembaga & Gianyar & 19. & Nangka & Gianyar \\
\hline
\end{tabular}


Fenny Martha Dwivany, Muhammad Rifki Ramadhan, Carolin Lim, Agus Sutanto, Husna Nugrahapraja, Ketut Wikantika, Sigit Nur Pratama, Karlia Meitha and Aksarani Sa Pratiwi

Table 1 (Continued)

\begin{tabular}{llllll}
\hline No & Cultivar & Locality & No & No Cultivar & Locality \\
\hline 21. & Klutuk & Denpasar & 31. & Bile & Buleleng \\
22. & Padi & Gianyar & 32. & Ketip Sari & Jembrana \\
23. & Muli Kuning & Gianyar & 33. & Raja Bulu & Gianyar \\
24. & Kaiki & Karangasem & 34. & Susu Hijau & Denpasar \\
25. & Siam & Gianyar & 35. & Panjang & Gianyar \\
26. & Kapal & Gianyar & 36. & Tanduk & Jembrana \\
27. & Bunga & Karangasem & 37. & Seribu & Klungkung \\
28. & Cavendish & Gianyar & 38. & Musa & Gianyar \\
29. & & Kelutina & \\
30. & Kole & Gianyar & & Musa ornata & Gianyar \\
\hline
\end{tabular}

Table 2

Locations of sample collection with the village of each regency and city

\begin{tabular}{|c|c|c|}
\hline Regency/City & Village & Coordinate of Global Positioning System \\
\hline Denpasar & Penatih & $8^{\circ} 36^{\prime} 28.79^{\prime \prime S}, 115^{\circ} 14^{\prime} 14.87^{\prime \prime E}$ \\
\hline \multirow[t]{3}{*}{ Gianyar } & Guwang & $8^{\circ} 36^{\prime} 39.23^{\prime \prime} \mathrm{S}, 115^{\circ} 17^{\prime} 23.82^{\prime \prime} \mathrm{E}$ \\
\hline & Celuk & $8^{\circ} 36^{\prime} 5.59 " \mathrm{~S}, 115^{\circ} 15^{\prime} 53.85^{\prime \prime} \mathrm{E}$ \\
\hline & Kerta & $8^{\circ} 19^{\prime} 49.64^{\prime \prime S}, 115^{\circ} 17^{\prime} 32.69^{\prime \prime} \mathrm{E}$ \\
\hline \multirow[t]{2}{*}{ Klungkung } & Besan & $8^{\circ} 31^{\prime} 5.73^{\prime \prime} \mathrm{S}, 115^{\circ} 27^{\prime} 5.85^{\prime \prime} \mathrm{E}$ \\
\hline & Pesinggahan & $8^{\circ} 32^{\prime} 58.88^{\prime \prime} \mathrm{S}, 115^{\circ} 27^{\prime} 27.02^{\prime \prime} \mathrm{E}$ \\
\hline Karangasem & Rendang & $8^{\circ} 25^{\prime} 41.02^{\prime \prime} \mathrm{S}, 115^{\circ} 25^{\prime} 7.79^{\prime \prime} \mathrm{E}$ \\
\hline Bangli & Jehem & $8^{\circ} 24^{\prime} 54.90^{\prime \prime} \mathrm{S}, 115^{\circ} 22^{\prime} 15.16^{\prime \prime} \mathrm{E}$ \\
\hline Buleleng & Anturan & $8^{\circ} 9^{\prime} 12.42^{\prime \prime S}, 115^{\circ} 3^{\prime} 4.93^{\prime \prime E}$ \\
\hline Badung & Abiansemal & $8^{\circ} 32^{\prime} 15.60^{\prime \prime} \mathrm{S}, 115^{\circ} 12^{\prime} 51.66^{\prime \prime} \mathrm{E}$ \\
\hline Tabanan & Marga & $8^{\circ} 25^{\prime} 51.67^{\prime \prime} \mathrm{S}, 115^{\circ} 10^{\prime} 34.55^{\prime \prime} \mathrm{E}$ \\
\hline Jembrana & Bading Kayu & $8^{\circ} 25^{\prime} 24.13^{\prime \prime S}, 114^{\circ} 54^{\prime} 59.59^{\prime \prime} \mathrm{E}$ \\
\hline
\end{tabular}




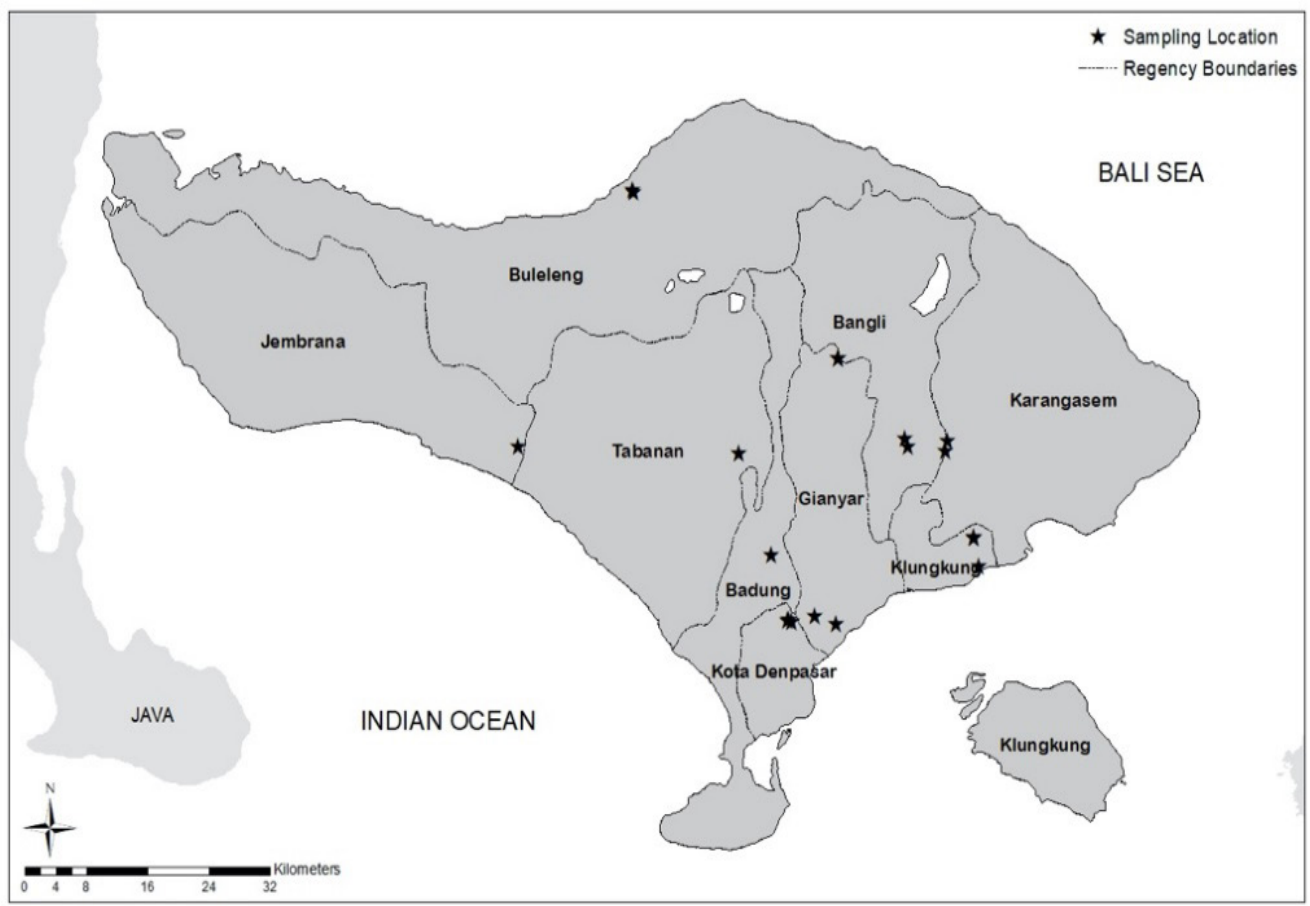

Figure 1. Sampling locations of banana cultivars in Bali island with stars showing the geographical position of Penatih, Guwang, Celuk, Kerta, Besan, Pesinggahan, Rendang, Jehem, Anturan, Abiansemal, Marga, and Bading Kayu area

\section{DNA Isolation and Amplification of ITS-2 Region}

Thirty-nine (39) samples had been collected and each sample had one replicate. All samples were ground using mortar and pestle with the help of liquid nitrogen, which was poured periodically until the sample became powdery fine. The DNA was isolated using the modified Doyle and Doyle method, by multiple washing and cleaning process using Isopropanol (Doyle \& Doyle, 1991). The quality and quantity of DNA isolates were measured using NanoDrop ${ }^{\mathrm{TM}}$ spectrophotometer. The 260/280 ratio was measured to check the quality and quantity of the DNA in which TE buffer was used as a solvent. Gene amplification was performed by polymerase chain reaction (PCR) method (initial denaturation temperature $94^{\circ} \mathrm{C}$ for 5 minutes, annealing temperature of $55^{\circ} \mathrm{C}$ for 30 seconds, and elongation temperature of $72^{\circ} \mathrm{C}$ for 10 minutes; with 40 denaturation cycle) (Meitha et al., 2020). The $50 \mu \mathrm{L}$ of PCR reaction comprised $5 \mu \mathrm{L}$ of DNA samples and mixed with $25 \mu \mathrm{L}$ of GoTaq ${ }^{\circledR}$ Green Master Mix (serial number: AF9PIM712 1016M712, Promega Co., USA), which consisted of DNA Polymerase, Reaction Buffer ( $\mathrm{pH}$ 8.5), $400 \mu \mathrm{M}$ dATP, $400 \mu \mathrm{M}$ dGTP, 400 
$\mu \mathrm{M} \mathrm{dCTP}, 400 \mu \mathrm{M} \mathrm{dTTP}$, and $3 \mathrm{mM} \mathrm{MgCl}_{2}$ (Promega Co., USA); $15 \mu \mathrm{L}$ of nucleasefree water; and $2.5 \mu \mathrm{L}$ of each of the primary ITS-S2F and ITS-S3R. The primer sequences used in the reaction were ITSS2F: 5'-ATGCGATACTTGGTGTGAAT-3' a $\mathrm{n} \mathrm{d}$ I $\mathrm{T}$ S $-\mathrm{S} 3 \mathrm{R}$ : 5'-GACGCTTCTCCAGACTACAAT-3' (Gu et al., 2013). The PCR results were confirmed using electrophoresis (agarose $1 \%$, TAE $1 \mathrm{x}$ buffer, $70 \mathrm{~V}-30$ minutes). The PCR amplified products were sequenced using Sanger sequencing platform via Macrogen Inc., South Korea. Samples that have been successfully sequenced then used to make contig using the CodonCode Aligner application (http://www.codoncode. com/aligner/).

\section{Prediction of ITS-2 Secondary Structure and Phylogram Construction}

The secondary structure ITS-2 region was predicted using ITS2 Database (http://its2. bioapps.biozentrum.uni-wuerzburg.de/) with E-value cut off less than 1e-16 and model possessing the highest transfer helices while as for motif prediction, E-value less than 0.01 and Viridiplantae model were opted (Keller et al., 2009; Koetschan et al., 2009). Multiple ITS2 sequences were aligned with ClustalX algorithm (Sievers \& Higgins, 2014), within an integrated program, namely SeaView 4 (Gouy et al., 2010). Consensus representation of multiple sequence alignment was illustrated using WebLogo 3 (http://weblogo.threeplusone. com/), and the probability of the bases are shown in bits unit (Crooks et al., 2004).
Logo consensus was manually juxtaposed to its motif prediction to depict the conserved nucleotides better.

We added other closely related plants of Musa (Ensete ventricosum, Ensete glaucum, and Musella lasiocarpa) to inquire further whether the ITS-2 sequences among them are conserved but adequately robust to different group species within Musaceae family. To provide a broader illustration of plant evolution and systematics through phylogeny, different ITS-2 sequences of various plants from 4 families were designated as operational taxonomical units (OTUs). Those group of plants collected from ITS2 Database were Strelitziaceae (Strelitzia reginae and Strelitzia alba), Poaceae (Hordeum vulgare, Zea mays, and Orzya sativa), Brassicaceae (Brassica rapa, Arabidopsis thaliana, and Arabidopsis lyrata), and Fabaceae (Medicago cretace and Medicago polyceratea) (Koetschan et al., 2009). ITS-2 rRNA sequences of Bali bananas have been uploaded to GenBank and can be freely accessed, whose accession numbers are MN718989-MN719027.

Phylogram construction comprised multiple sequence alignment, tree inference, and visualization. Firstly, ITS-2 (51 OTUs) sequences were aligned with ClustalX software (Sievers \& Higgins, 2014). The tree was inferred using neighbor joining (NJ) with Kimura-2-parameter (K2P) model and 1,000 bootstrap disturbances using SeaView program (Gouy et al., 2010). To compare, we managed to construct a phylogram using the same tree inference method enriched with secondary structure 
information of ITS- 2 sequence using Clustal algorithm coupled with LocARNA program (Will et al., 2012). Last, trees were visualized and annotated using FigTree 1.4.4 (Rambaut, 2018).

\section{RESULTS AND DISCUSSION}

\section{Amplification of ITS-2 Area}

The ITS-2 region amplification produced fragments with a size of $\sim 500 \mathrm{bp}$. The amplified products did not only consist of the ITS-2 region, which based on the literature had a length of 205 bp to $227 \mathrm{bp}$ (Hřibová et al., 2011), but also the 5.8S rDNA region and the $28 \mathrm{~S}$ rDNA region which were the flanking sequences of the ITS-2 region (Yao et al., 2010). This was not a problem in constructing the phylogeny of ITS-2 due to a trimming process that was conducted following ITS-2 annotation. The visualization of the amplification results can be seen in Figure 2.

\section{ITS-2 Secondary Structure}

We evaluated the secondary structure of ITS of $M$. acuminata (A genome donor) and $M$. balbisiana (B genome donor), as shown in Figure 3. A variety of molecular and evolution mechanisms have resulted in ITS-2 that can be distinguished based on their secondary structure. The most striking differences observed were the internal loop size and the extra loop in helix I in B genome (Figure 3B) compared to the A genome (Figure 3A). We also found that from the alignment of Bali bananas represented in logo consensus, the first motif of U-U mismatch (II left) was the least conserved motif among the other three motifs.

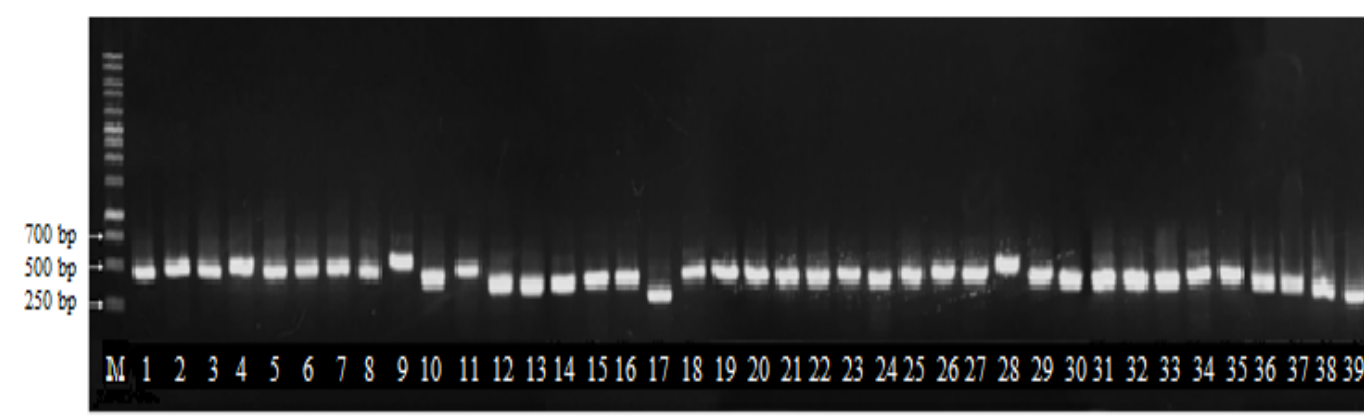

Figure 2. Electrophoregram of DNA amplicons of 5.8S rDNA, ITS-2, and 28S rDNA of 37 banana cultivated varieties, Musa ornata, and Musa velutina with no band shearing: $\mathrm{M}=1 \mathrm{~kb}$ DNA marker ladder, $1=\mathrm{Kayu}$, $2=$ Sabe Macan, 3 = Mas, $4=$ Sangket, $5=$ Keladi, $6=$ Tulang, $7=$ Raja Molo, $8=$ Tembaga, $9=$ Gancan, $10=$ Sobo, $11=$ Buah, $12=$ Ketip Kerta, $13=$ Poh, $14=$ Bali, $15=$ Lumut, $16=$ Ambon Kuning, $17=$ Mas Marlin, $18=$ Nangka, $19=$ Ketip Tulang, $20=$ Klutuk, $21=$ Padi, $22=$ Muli Kuning, $23=$ Kaiki, $24=$ Siam, $25=$ Kapal, $26=$ Bunga, $27=$ Cavendish, $28=$ Kepok, $39=$ Kole, $30=$ Bile, $31=$ Ketip Sari, $32=$ Raja Bulu, $33=$ Susu Hijau, $34=$ Panjang, $35=$ Tanduk, $36=$ Seribu, $37=$ Kepok Tanjung, $38=$ Musa ornata, and $39=$ Musa velutina. The bands are shown to have lengths of $500 \mathrm{bp}$, hence the flanking sequences were trimmed to produce the ITS-2 sequence only 
A

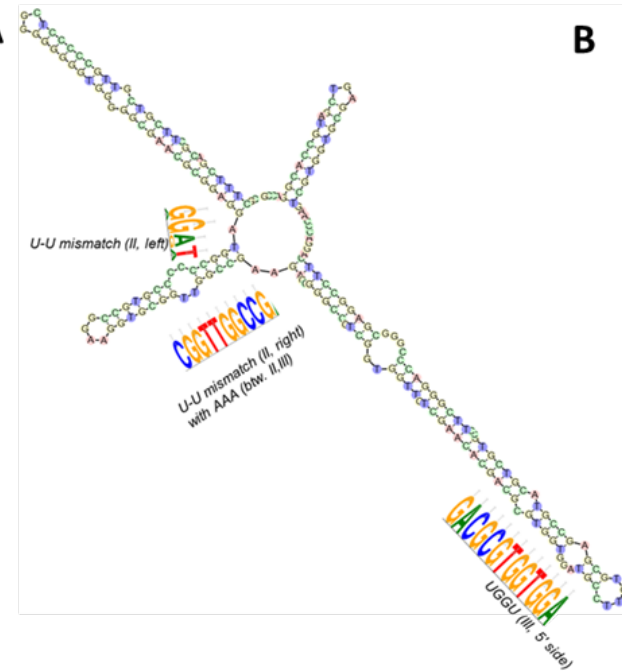

B

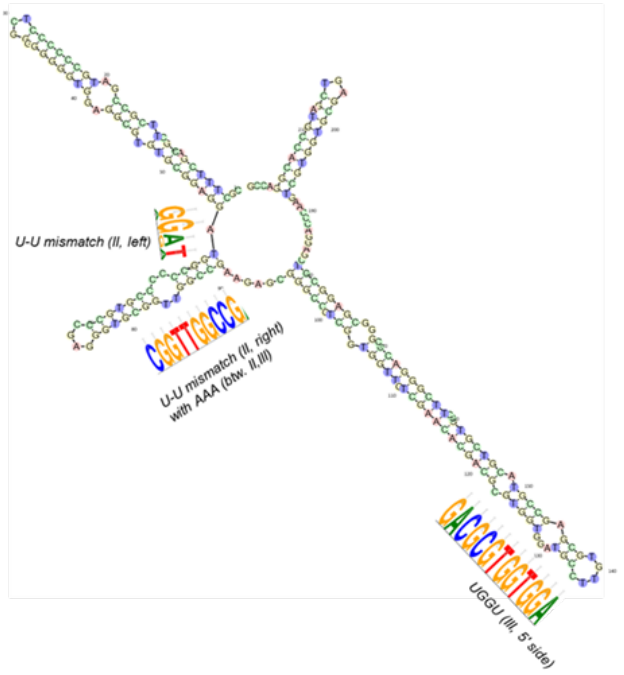

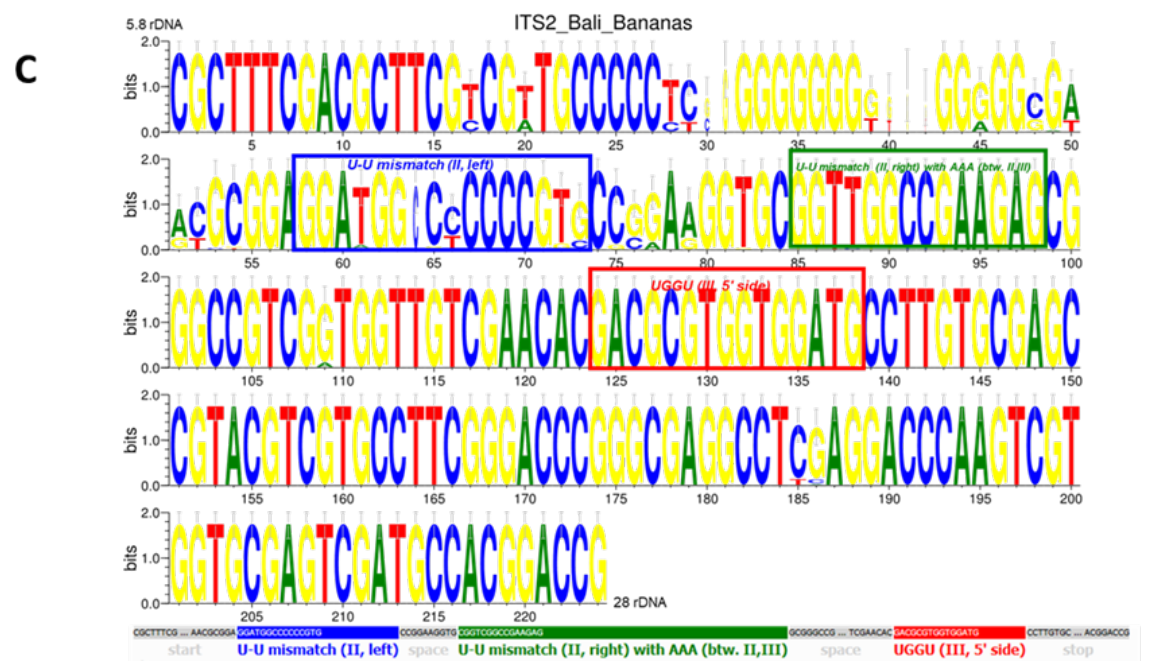

Figure 3. Secondary structure and motif prediction of ITS-2: A) secondary structure of ITS-2 predicted from A genome banana, B) secondary structure of ITS-2 predicted from B genome banana, and C) consensus of ITS-2 sequences of 32 banana cultivars represented in nucleotides logo $(\mathrm{C}=$ blue, $\mathrm{G}=$ yellow, $\mathrm{T}=$ red, $\mathrm{A}=$ green). The probability of each nucleotide is represented in bits unit. The $224 \mathrm{bp} \mathrm{ITS}-2$ is paired with the motif prediction comprises start, two spacers, three motifs (represented in boxes outlined with blue, green, and red colors), and stop sequence 
ITS-2 functional secondary structure is proven to be conserved in plants DNA (Hershkovitz \& Zimmer, 1996; Jobes \& Thien, 1997). ITS-2 spacer had four unique helices structure, as shown in Figure 4, and the analysis of the two-dimensional structure proved that the structure was highly conserved throughout the eukaryotes (Schultz et al., 2005). Helix II is characterized by the content of pyrimidinepyrimidine nodules. Helix III characterized as the longest and containing the most conserved primer on 5' includes TGGT (UGGU sequences for RNA) sequence (Schultz et al., 2005). As for helix, I and IV are more diverse, and only helix II and III that could be identified in general to all eukaryote (Coleman, 2007). The functions of ITS-2 as spacer are largely unknown, and ITS-2 sequences are not incorporated into the mature rRNA. Nevertheless, they encode signals for the rRNA transcripts processing properly (Hillis \& Dixon, 1991). This inferred function is itself dependent on secondary structure of the ITS RNA.

\section{Phylogenetic Tree Analysis}

Standard multiple sequence alignment programs, such as MAFFT (Katoh \& Standley, 2013) or T-Coffee (Notredame et al., 2000), cannot be used to construct a phylogenetic tree by including the secondary structure information. Rather, these tools use virtually similar approaches based on nucleotides information such as similarity. Despite significant variations in nucleotides, the ITS-2 secondary structure has been described to be highly conserved, possessing four helices and motifs (Schultz et al., 2005). As an alternative, combining multiple loci of gene markers with the ITS- 2 will provide a better substitute to infer a phylogenetic tree. The demerit of using additional loci is that it is time-consuming and can be costly; furthermore, adding nucleotides information does not guarantee the truest evolutionary history (Huelsenbeck et al., 1996).

To provide a comparison, we inferred trees using two alignments: nucleotides information-based and one with additional secondary structure information, as shown in Figure 4.

To analyze the genetic variability among Musa species and the family of Musaceae, we also studied other families of Strelitziaceae, Poaceae, Brassicaceae, and Fabaceae. Coupled with additional OTUs of Ensete and Musella species, this strategy hopefully can shed light in terms of ITS-2 usefulness. Particularly, it may provide a depiction of major and minor classification in plants. Based on the same taxa of families, both phylograms, as shown in Figure 4, showed a consistent clade clustering. Our analyses showed the monophyletic origin of Musaceae comprised Musa, Ensete, and Musella species, this result is concordant to previous analysis (Hřibová et al., 2011). Musaceae is shown to closely relate to Strelitziaceae as they are the group in order of Zingiberales. Given two types of strategies in constructing the phylogenetic tree, the secondary structure is far more conserved in comparison with the nucleotide sequences. The genera of Ensete and Musella are not shown as outgroups 
Fenny Martha Dwivany, Muhammad Rifki Ramadhan, Carolin Lim, Agus Sutanto, Husna Nugrahapraja, Ketut Wikantika, Sigit Nur Pratama, Karlia Meitha and Aksarani Sa Pratiwi
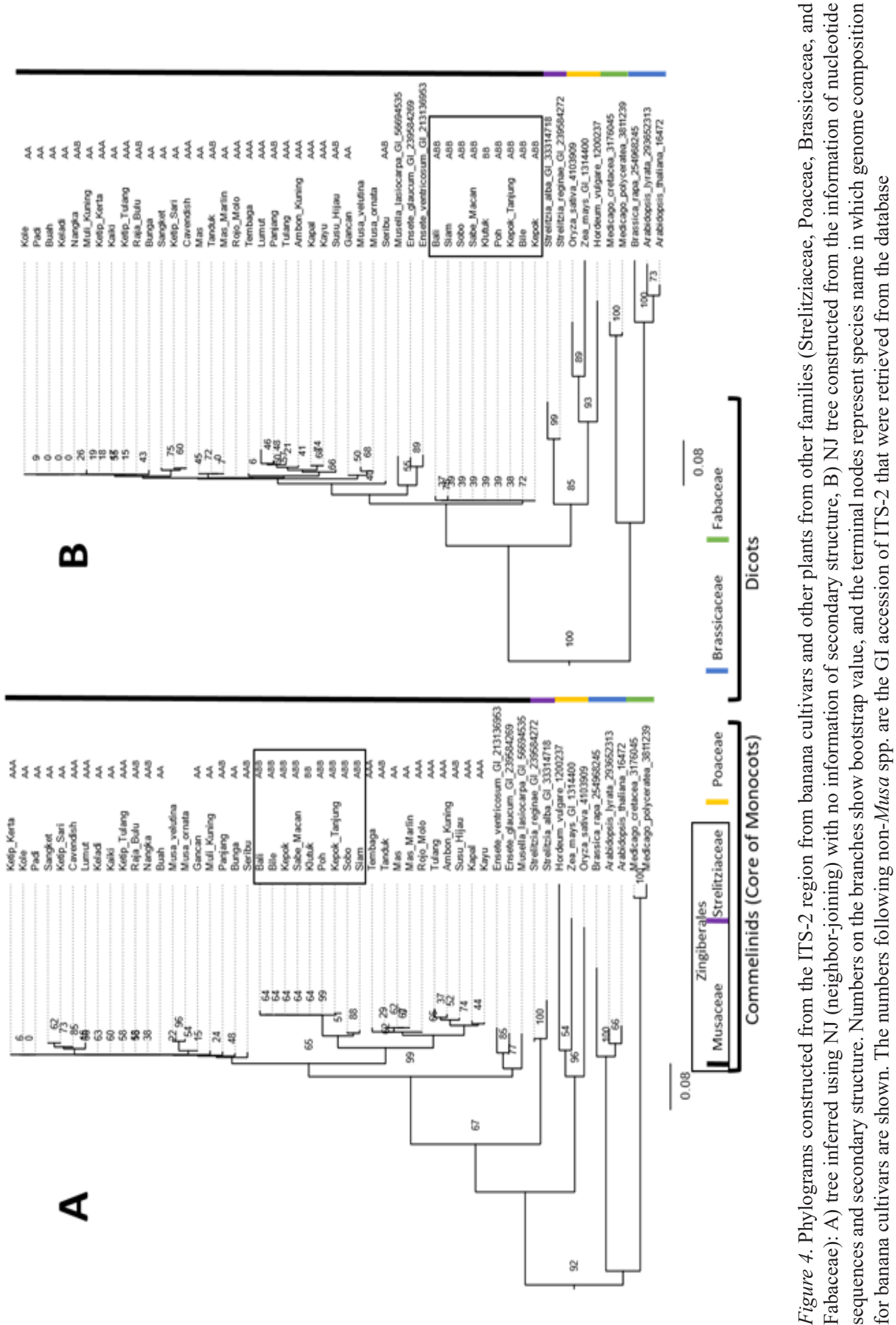
within Musa clade in the tree constructed from nucleotide and secondary structure information (Figure 3B).

The monophyletic group of subclass of commelinids, known as the core of monocots, has been described as a closely related group based on molecular analysis (Barrett et al., 2013). The group of comelinids, such as corn (Zea mays), barley (Hordeum vulgare), and paddy (Oryza sativa) are shown topologically close to bananas. Not only they have extant similar phenotypic characteristics, but they also have a close molecular relationship based on ITS-2 rDNA analysis. Liliopsida (monocots) groups are shown as distant relatives meaning a greater variance above taxa of families was observed.

The drawback of using the ITS-2 rDNA marker in phylogenetic analysis is that ITS-2 may be heterogeneous. This characteristic can be understood by its presence in plant species and polyploid ones as multiple divergent ITS sequences in several loci. ITS-2 sequences have been used in a wide range of taxonomy analysis ranging from order to subspecies while other barcoding markers such as rbcL (gene encoding ribulose biphosphate carboxylase large chain) and (mitochondrial DNA) mtDNA have narrower ranges (Coleman, 2003). Although their versatility of usefulness, ITS2 sequences appeared to be less conserved (differ too much) in major groups or higher taxa (Baldwin et al., 1995). We found that this claim could be well-conceived as we evaluated the alignment of different families, particularly in the subdivision of dicots.
Thus, the strategy used in choosing an alignment approach remained a challenging task.

One of the intricate comprehensions in phylogenetics is polytomy, a clade of OTUs that are not formed a series of two way-splits. Commonly, this phenomenon appears as a result of unresolved phylogeny owing to the limitedness of phylogenetic software (Slowinski, 2001). This is not the case when it comes to several ITS-2 region clusters. Our data showed that some banana cultivars have $100 \%$ identity, such as in the B genome group, and appeared as a polytomy. Subsequently, we reconstructed the trees by excluding non-banana plants as well as ornamental bananas (M. velutina and M. ornata) (Figure 5).

The phylogenetic trees in Figure 5 show that the OTUs based on ITS-2 were clustered according to their families in which banana cultivars were grouped into two clades indicating their dominant genome composition: A genome and B genome. This clade described the genome composition of the banana cultivar. The first clade contained banana cultivars that had the genome AA, AAA, and AAB. In the second clade, banana cultivars had the genomic composition of $\mathrm{ABB}$ and $\mathrm{BB}$. In conclusion, ITS-2 region can be used to classify banana species rather than banana cultivars. However, the closely related $M$. velutina and $M$. ornata made the clustering analysis seemed complicated (Figure 4). Constructed trees of ingroup edible bananas (nucleotide information only and one added with secondary structure information) seem to have similar topology 


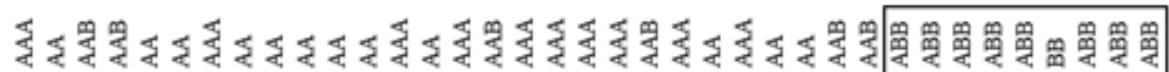

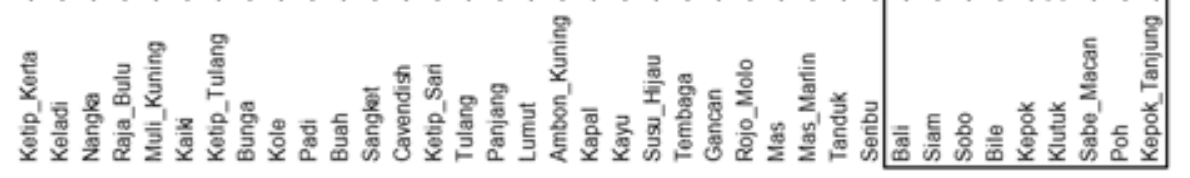

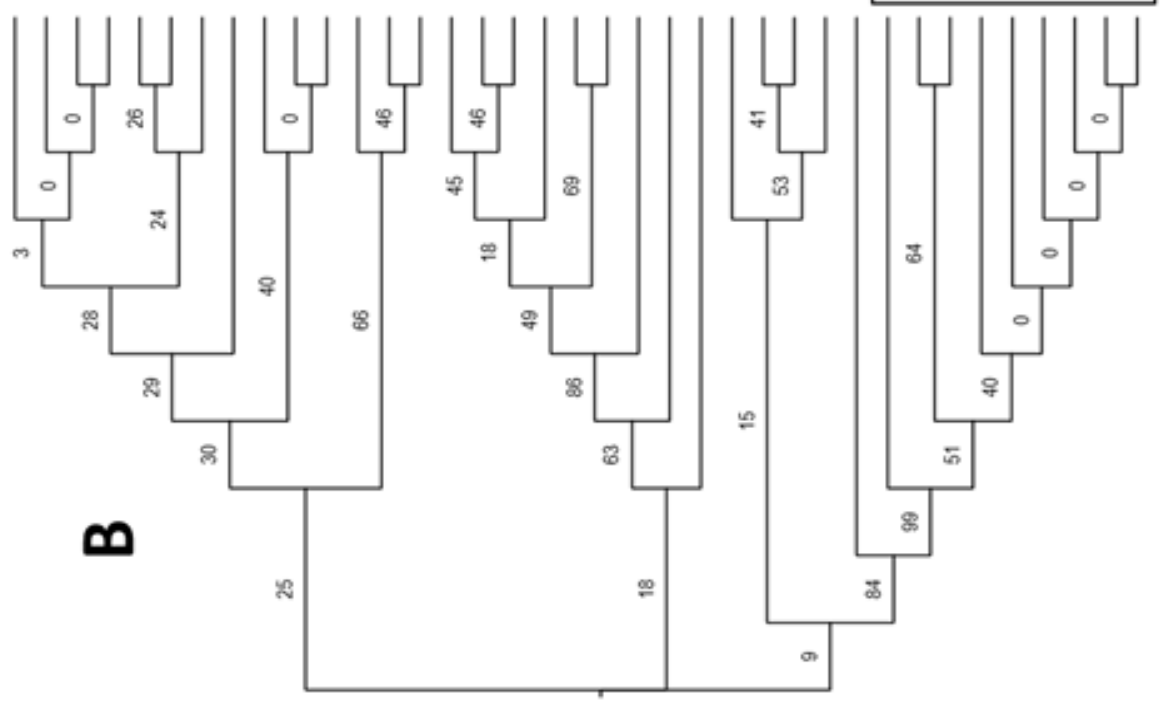

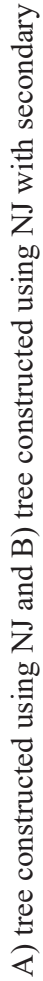

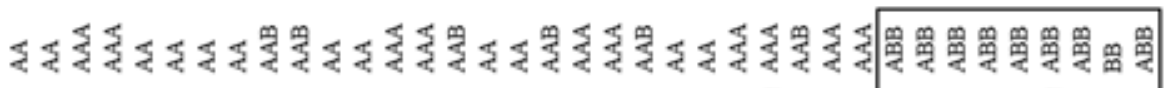

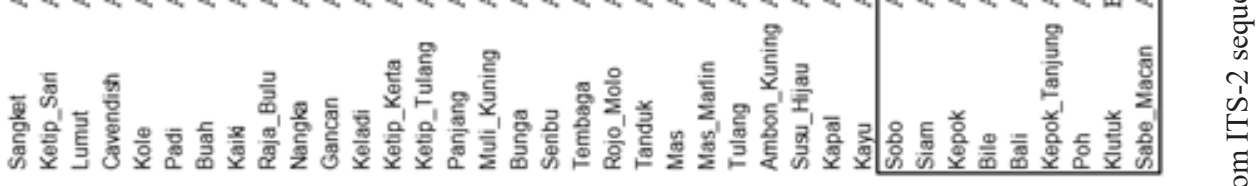

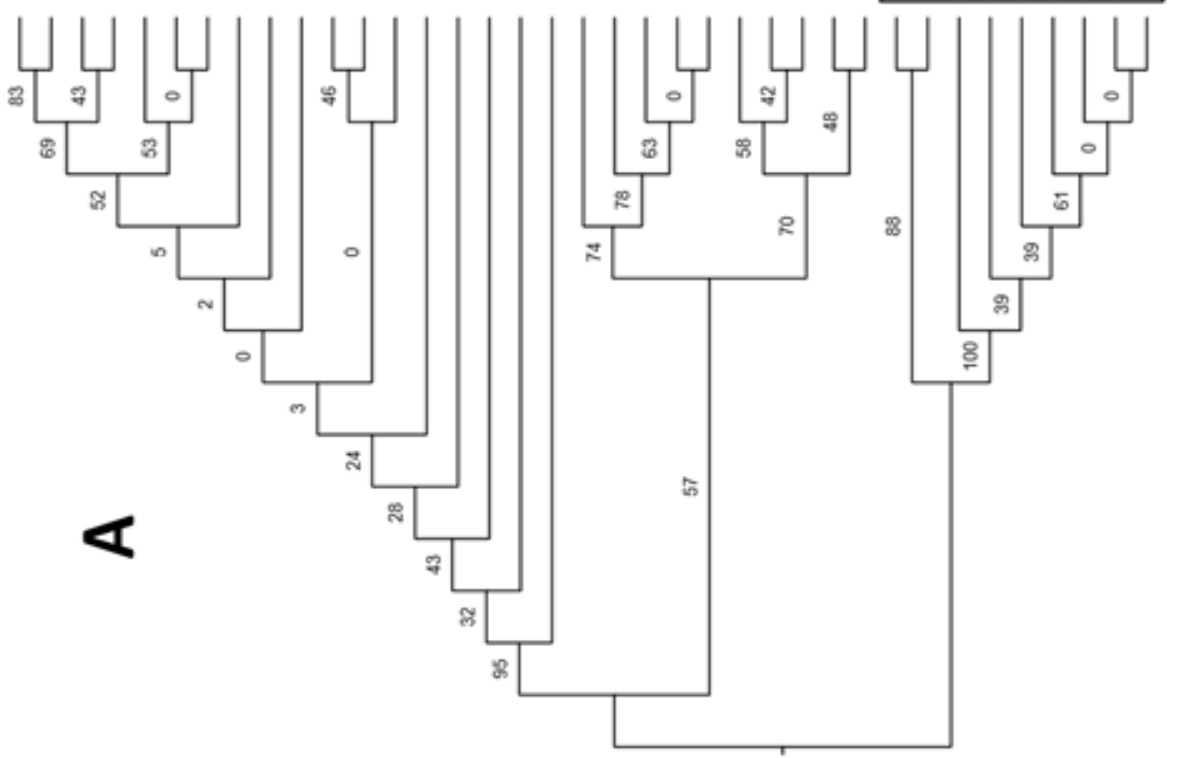


and cluster (Figure 5). Both strategies were able to group bananas based on their genome composition even though the $\mathrm{B}$ genome group was clearly separated in the former strategy.

In terms of Bali bananas diversity, it is also imperative to be concerned about the cultivation and conservation of useful cultivars such as 'Kayu AAA' and 'Bile ABB' cultivar (also known as 'Haji' cultivar in Nusa Tenggara). 'Kayu' cultivar possesses distinctive value since the variety is only cultivated in Bali island, generally harnessed for offering in ceremonies (Rai et al., 2018).

Being one of the most diverse cultivars resulting from several wild species crossing, bananas have more than thousand of cultivars. Molecular barcoding such as this is beneficial to evaluate the diversity of bananas regarding their chromosomal genome character. Further analysis of multiple ITS-2 sequence types origin in terms of evolutionary mechanisms, and their utilization can shed some light on genome relationship and polyploid ancestry (Bailey et al., 2003; Dadejová et al., 2007). Banana cultivars that have a relative proportion of similar genome compositions are placed in the same clade. Thus the molecular relationship of them is closer than that of a banana cultivar with a different relative proportion of genomic compositions. By juxtaposing two phylograms, we observed that additional information from a secondary structure could provide a stronger resolving power in phylogenetic analysis rather than just solely relying on nucleotide information.

\section{CONCLUSION}

This study showed that from thirty-nine banana samples from Bali island, two clades were formed, one clade was abundant in A genome (AA and AAA), and the other rich in the $\mathrm{B}$ genome (BB and $\mathrm{ABB})$. This ITS2 study also suggested that cultivars with similar genomic compositions would tend to be grouped within the same clade.

\section{ACKNOWLEDGEMENTS}

We would like to acknowledge Riset Dikti (NK: 002/SP2H/PTNBH/DRPM/2019) for funding the research.

\section{CONFLICT OF INTEREST}

The authors declare that they have no conflict of interest.

\section{REFERENCES}

Bailey, C. D., Carr, T. G., Harris, S. A., \& Hughes, C. E. (2003). Characterization of angiosperm nrDNA polymorphism, paralogy, and pseudogenes. Molecular Phylogenetics and Evolution, 29(3), 435-455. doi: 10.1016/j.ympev.2003.08.021

Baldwin, B. G., Sanderson, M. J., Porter, J. M., Wojciechowski, M. F., Campbell, C. S., \& Donoghue, M. J. (1995). The ITS region of nuclear ribosomal DNA: A valuable source of evidence on Angiosperm phylogeny. Annals of the Missouri Botanical Garden, 82(2), 247-277. doi: $10.2307 / 2399880$

Barrett, C. F., Davis, J. I., Leebens-Mack, J., Conran, J. G., \& Stevenson, D. W. (2013). Plastid genomes and deep relationships among the commelinid monocot angiosperms. Cladistics, 29(1), 65-97. doi: 10.1111/j.1096-0031.2012.00418.x

Coleman, A. W. (2003). ITS2 is a double-edged tool for eukaryote evolutionary comparisons. Trends 
Fenny Martha Dwivany, Muhammad Rifki Ramadhan, Carolin Lim, Agus Sutanto, Husna Nugrahapraja, Ketut Wikantika, Sigit Nur Pratama, Karlia Meitha and Aksarani Sa Pratiwi

in Genetics, 19(7), 370-375. doi: 10.1016/S01689525(03)00118-5

Coleman, A. W. (2007). Pan-eukaryote ITS2 homologies revealed by RNA secondary structure. Nucleic Acids Research, 35(10), 33223329. doi: 10.1093/nar/gkm233

Crooks, G. E., Hon, G., Chandonia, J. M., \& Brenner, S. E. (2004). WebLogo: A sequence logo generator. Genome Research, 14(6), 1188-1190. doi: $10.1101 /$ gr.849004

Dadejová, M., Lim, K. Y., Soucková-Skalická, K., Matyášek, R., Grandbastien, M. A., Leitch, A., \& Kovařík, A. (2007). Transcription activity of rRNA genes correlates with a tendency towards intergenomic homogenization in Nicotiana allotetraploids. New Phytologist, 174(3), 658668. doi: 10.1111/j.1469-8137.2007.02034.x

De Langhe, E., Vrydaghs, L., de Maret, P., Perrier, X., \& Denham T. P. (2009). Why bananas matter: An introduction to a history of banana domestication. Ethnobotany Research and Application, 7, 165177. doi: 10.17348/era.7.0.165-177

Doyle, J., \& Doyle, J. L. (1991). DNA isolation from small amounts of plant tissue. Phytochemical Bulletin, 57, 13-15. doi: 10.2307/4119796

Gouy, M., Guindon, S., \& Gascuel, O. (2010). Sea view version 4: A multiplatform graphical user interface for sequence alignment and phylogenetic tree building. Molecular Biology and Evolution, 27(2), 221-224. doi: 10.1093/ molbev/msp259

Gu, W., Song, J., Cao, Y., Sun, Q., Yao, H., Wu, Q., ... Duan, J. (2013). Application of the ITS2 region for barcoding medicinal plants of Selaginellaceae in Pteridophyta. PLOS One, 8(6), e67818. doi: 10.1371/journal.pone.0067818

Guzow-Krzemińska, B., \& Wȩgrzyn, G. (2000). Potential use of restriction analysis of PCRamplified DNA fragments in construction of molecular data-based identification keys of lichens. Mycotaxon, 76, 305-313.
Hapsari, L., Azrianingsih, R., \& Arumingtyas, E. L. (2018). Genetic variability and relationship of banana cultivars (Musa L.) from East Java, Indonesia based on the internal transcribed spacer region nrDNA sequences. Journal of Tropical Biology and Conservation, 15(1), 101-120. doi: 10.12692/ijb/7.3.42-52.

Hapsari, L., Kennedy, J., Lestari, D. A., Masrum, A., \& Lestarini, W. (2017). Ethnobotanical survey of bananas (Musaceae) in six districts of East Java, Indonesia. Biodiversitas, 18(1), 160-174. doi: 10.13057/biodiv/d180123

Hershkovitz, M. A., \& Zimmer, E. A. (1996). Conservation patterns in angiosperm rDNA ITS2 sequences. Nucleic Acids Research, 24(15), 2857-2867. doi: 10.1093/nar/24.15.2857

Hillis, D. M., \& Dixon, M. T. (1991). Ribosomal DNA: Molecular evolution and phylogenetic inference. The Quarterly Review of Biology, 66(4), 411-453. doi: 10.1086/417338

Hřibová, E., Č́ížková, J., Christelová, P., Taudien, S., de Langhe, E., \& Doležel, J. (2011). The ITS15.8S-ITS2 sequence region in the Musaceae: Structure, diversity and use in molecular phylogeny. PLOS One, 6(3), e17863. doi: 10.1371/journal.pone.0017863

Huelsenbeck, J. P., Bull, J. J., \& Cunningham, C. W. (1996). Combining data in phylogenetic analysis. Trends in Ecology and Evolution, 11(4), 152-158. doi: 10.1016/0169-5347(96)10006-9

Jobes, D. V., \& Thien, L. B. (1997). A conserved motif in the $5.8 \mathrm{~S}$ ribosomal RNA (rRNA) gene is a useful diagnostic marker for plant internal transcribed spacer (ITS) sequences. Plant Molecular Biology Reporter, 15(4), 326-334. doi: 10.1023/A:1007462330699

Katoh, K., \& Standley, D. M. (2013). MAFFT multiple sequence alignment software version 7: Improvements in performance and usability. Molecular Biology and Evolution, 30(4), 772780. doi: 10.1093/molbev/mst010 
Keller, A., Schleicher, T., Schultz, J., Müller, T., Dandekar, T., \& Wolf, M. (2009). 5.8S-28S rRNA interaction and HMM-based ITS2 annotation. Gene, 430(1-2), 50-57. doi: 10.1016/j.gene.2008.10.012

Koetschan, C., Förster, F., Keller, A., Schleicher, T., Ruderisch, B., Schwarz, R., ... Schultz, J. (2009). The ITS2 Database III - Sequences and structures for phylogeny. Nucleic Acids Research, 38(supp1_1), D275-D279. doi: $10.1093 / \mathrm{nar} / \mathrm{gkp} 966$

Meitha, K., Fatmawati, I., Martha Dwivany, F., Sutanto, A., Nur Pratama, S., Nugrahapraja, H., \& Wikantika, K. (2020). Phylogenetic analysis of 23 accessions of Indonesian banana cultivars based on internal transcribed spacer 2 (ITS2) region. Indonesian Journal of Biotechnology, 25(1), 1-11. doi: 10.22146/ijbiotech.49506

Nelson, S. C., Ploetz, R. C., \& Kepler, A. K. (2006). Musa species (banana and plantain) (Ver. 2.2). In C. R. Elevitch (Ed.), Species profiles for Pacific island agroforestry (pp. 1-33). Hōlualoa, Hawaii: Permanent Agriculture Resources (PAR).

Notredame, C., Higgins, D. G., \& Heringa, J. (2000). T-coffee: A novel method for fast and accurate multiple sequence alignment. Journal of Molecular Biology, 302(1), 205-217. doi: 10.1006/jmbi.2000.4042

Pillay, M., \& Tenkouano, A. (2011). Banana breeding: Progress and challenges. Boca Raton, USA: CRC Press - Taylor and Francis Group.

Poczai, P., \& Hyvönen, J. (2010). Nuclear ribosomal spacer regions in plant phylogenetics: Problems and prospects. Molecular Biology Reports, 37(4), 1897-1912. doi: 10.1007/s11033-009-9630-3
Rai, I. N., Dwivany, F. M., Sutanto, A., Meitha, K., Sukewijaya, I. M., \& Ustriyana, I. N. G. (2018). Biodiversity of Bali banana (Musaceae) and its usefulness. HAYATI Journal of Biosciences, 25(2), 47-53. doi: 10.4308/hjb.25.2.47

Rambaut, A. (2018). FigTree v. 1.4.4. Retrieved 10 June, 2020, from http://Tree.Bio.Ed.Ac.Uk/ Software/Figtree/

Schultz, J., Maisel, S., Gerlach, D., Müller, T., \& Wolf, M. (2005). A common core of secondary structure of the internal transcribed spacer 2 (ITS2) throughout the Eukaryota. RNA, 11(4), 361-364. doi: 10.1261/rna.7204505

Sievers, F., \& Higgins, D. G. (2014). Clustal Omega, accurate alignment of very large numbers of sequences. Methods in Molecular Biology, 1079, 105-116. doi: 10.1007/978-1-62703-646-7_6

Slowinski, J. B. (2001). Molecular polytomies. Molecular Phylogenetics and Evolution, 19(1), 114-120. doi: 10.1006/mpev.2000.0897

Will, S., Joshi, T., Hofacker, I. L., Stadler, P. F., \& Backofen, R. (2012). LocARNA-P: Accurate boundary prediction and improved detection of structural RNAs. RNA, 18(5), 900-914. doi: 0.1261/rna.029041.111

Yao, H., Song, J., Liu, C., Luo, K., Han, J., Li, Y., ... Chen, S. (2010). Use of ITS2 region as the universal DNA barcode for plants and animals. PLOS One, 5(10), e13102. doi: 10.1371/journal. pone.0013102

Zhang, W., Yuan, Y., Yang, S., Huang, J., \& Huang, L. (2015). ITS2 secondary structure improves discrimination between medicinal "Mu Tong" species when using DNA barcoding. PLOS One, 10(7), e0131185. doi: 10.1371/journal. pone. 0131185 
